\title{
Respiratory System Part
}

National Cancer Institute

\section{Source}

National Cancer Institute. Respiratory System Part. NCI Thesaurus. Code C13037.

Any component of the org ans involved in the exchange of carbon dioxide and oxygen

including the trachea, bronchi, bronchial tubes, lungs, and alveoli. 